Volume 2 Nomor 2, September 2020, Halaman 95 - 106.

\title{
A BILGATES DAN SI DIA (AWALI BIASAKAN CEGAH DIABETES DAN ATASI DIABETES)
}

\author{
Tating Nuraeni' ${ }^{1)}$, Roifatun Nisa ${ }^{2)}$, Laesya Nurhayatul Mardiah ${ }^{3)}$ \\ Linda Iryani ${ }^{4)}$, dan Uswatun Khasanah ${ }^{5)}$ \\ ${ }^{1,2,3,4,5)}$ Program Studi Kesehatan Masyarakat Universitas Wiralodra \\ Email : tatingnuraeni@unwir.ac.id, yumerosha@gmail.com, \\ icalaesya85@gmail.com, lindairyani19@gmail.com, \\ hamasahfethorus@gmail.com
}

\begin{abstract}
Abstrak
Pengabdian kepada masyarakat ini dilakukan karena mayoritas masyarakat di Desa Lamaran Tarung berprofesi sebagai petani yang cenderung abai dan tidak menerapkan pola hidup yang sehat, khususnya mengenai pola makannya. Hal ini menyebabkan angka penderita Diabetes Mellitus di desa tersebut cukup tinggi dan terus mengalami peningkatan. Oleh sebab itu, dilakukanlah pengabdian kepada masyarakat ini guna menambah pengetahuan masyarakat mengenai Diabetes Mellitus dan meningkatkan kesadaran mereka mengenai pentingnya menerapkan pola hidup yang sehat. Pengabdian ini dilakukan pada bulan November 2020 di Desa Lamaran Tarung, Kecamatan Cantigi, Kabupaten Indramayu, dengan menggunakann metode pendekatan berupa penyuluhan (ceramah dan diskusi) mengenai Diabetes Mellitus, pendemonstrasian pembuatan kopi biji rambutan, dan observasi. Hasil dari kegiatan pengabdian masyarakat ini adalah bertambahnya pengetahuan masyarakat di Desa Lamaran Tarung khususnya yang terlibat dalam pengabdian ini mengenai Diabetes Mellitus. Selain itu, masyarakat menjadi tahu mengenai khasiat dari biji rambutan untuk mengatasi Diabetes Mellitus dan cara mengolahnya menjadi ramuan kopi biji rambutan.
\end{abstract}

Kata kunci: Kopi biji rambutan, Diabetes Mellitus, Pencegahan.

\begin{abstract}
This community service is carried out because the majority of people in Lamaran Tarung Village work as farmers who tend to be ignorant and do not follow a healthy lifestyle, particularly regarding their diet. This causes the number of Diabetes Mellitus sufferers in the village to be very high and continues to increase. In order to raise public awareness of Diabetes Mellitus and increase their awareness of the value of a healthy lifestyle, this community service is therefore carried out. The service was conducted in Lamaran Tarung Village, Cantigi Subdistrict, Indramayu Regency in November 2020, using an approach method in the form of advice (lectures and discussions) on diabetes. The outcome of this operation of community
\end{abstract}


service is the increased awareness of the community in Lamaran Tarung Village, especially those involved in this Diabetes Mellitus service. In addition, the public is aware of the properties of rambutan seeds for the treatment of Diabetes Mellitus and how they are formulated into a coffee brew of rambutan beans.

Keywords: Rambutan bean coffee, Diabetes Mellitus, Prevention.

\section{A. Pendahuluan}

Mitra berlokasi di Desa Lamaran Tarung Kecamatan Cantigi, lokasi mitra ini berada di wilayah kerja UPTD Puskesmas Cantigi. Penduduk desa lamaran Tarung berdasarkan jenis kelamin laki- laki sebanyak 4106 dan perempuan sebanyak 3094. Luas desa lamaran tarung sebesar 5.895 Ha. Penyakit Tidak Menular (PTM), termasuk Diabetes, saat ini telah menjadi ancaman serius kesehatan global. Dikutip dari data WHO 2016, 70\% dari total kematian di dunia dan lebih dari setengah beban penyakit. 90-95\% dari kasus Diabetes adalah Diabetes Tipe 2 yang sebagian besar dapat dicegah karena disebabkan oleh gaya hidup yang tidak sehat. Indonesia juga menghadapi situasi ancaman diabetes serupa dengan dunia. International Diabetes Federation (IDF) Atlas 2017 melaporkan bahwa epidemi Diabetes di Indonesia masih menunjukkan kecenderungan meningkat. Indonesia adalah negara peringkat keenam di dunia setelah Tiongkok, India, Amerika Serikat, Brazil dan Meksiko dengan jumlah penyandang Diabetes usia 20-79 tahun sekitar 10,3 juta orang. Sejalan dengan hal tersebut, Riset Kesehatan Dasar (Riskesdas) memperlihatkan peningkatan angka prevalensi Diabetes yang cukup signifikan, yaitu dari 6,9\% di tahun 2013 menjadi 8,5\% di tahun 2018

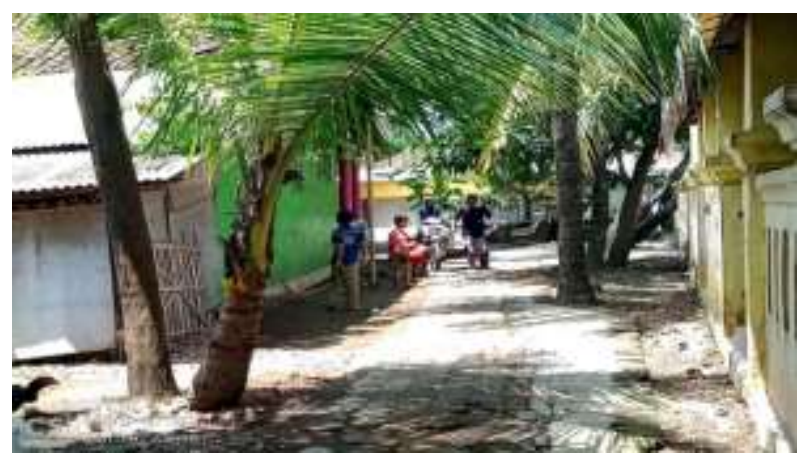

\section{Gambar 1. Keadaan Lokasi Desa Lamaran Tarung}

Berdasarkan gambar di atas dapat dilihat bahwa keadaan atau kondisi di Desa Lamaran Tarung masih terbilang asri dan sejuk. Masyarakatnya pun masih 
menjunjung tinggi kebersamaan. Akan tetapi, masih kurangnya kesadaran masyarakat tentang kesehatan mereka.

Penduduk Desa Lamaran Tarung sebagian besar masih banyak yang mengidap penyakit Diabetes Mellitus. Berdasarkan data yang diperoleh dari petugas surveilans UPTD Puskesmas Cantigi masyarakat di Desa Lamaran Tarung memiliki angka penderita penyakit Diabetes Mellitus yang cukup tinggi yaitu sebanyak 30\% dari jumlah penduduknya.

Selain itu mayoritas masyarakat Desa Lamaran Tarung berprofesi sebagai petani. Taraf perekonomian yang tidak merata inilah yang menyebabkan masyarakat sering mengabaikan kondisi kesehatan mereka serta makanan yang mereka konsumsi. Mereka sering kali abai akan kebutuhan nutrisi yang harus dipenuhi oleh tubuh, masyarakat cenderung lebih mementingkan kuantitas dari pada kualitasnya atau dengan kata lain mereka lebih mengutamakan memakan sesuatu yang membuat mereka kenyang tanpa peduli apakah kebutuhan nutrisi mereka terpenuhi atau tidak.

Berdasarkan analisis situasi di lingkungan mitra maka dapat disimpulkan bahwa permasalahan yang dialami mitra antara lain, tingkat perekonomian yang relatif rendah yang menyebabkan masyarakat cenderung tidak terlalu mempedulikan kesehatan dan pola hidup mereka khususnya pola makannya, dan kurangnya pemahaman masyarakat di Desa Lamaran Tarung mengenai pencegahan serta cara mengatasi Diabetes Mellitus.

Program penyuluhan kesehatan ini bertujuan untuk memberikan solusi atas permasalahan kesehatan tersebut di Desa Lamaran Tarung yang berlokasi di wilayah kerja UPTD Puskesmas Cantigi, Kecamatan Cantigi- Kabupaten Indramayu.

Diabetes Melitus (DM) merupakan suatu penyakit menahun yang ditandai dengan kadar glukosa darah (gula darah) melebihi normal yaitu kadar gula darah sewaktu sama atau lebih dari $200 \mathrm{mg} / \mathrm{dl}$, dan kadar gula darah puasa di atas atau sama dengan 126 mg/dl (Misnadiarly, 2006). DM dikenal sebagai silent killer karena sering tidak disadari oleh penyandangnya dan saat diketahui sudah terjadi komplikasi (Kemenkes RI, 2014). DM dapat menyerang hampir seluruh sistem tubuh manusia, mulai dari kulit sampai jantung yang menimbulkan komplikasi. 
ABDI WIRALODRA

JURNAL PENGABDIAN KEPADA MASYARAKAT
ISSN 2656-5501 (Print)

ISSN 2714-8041 (Online)

Diabetes Mellitus adalah kelompok penyakit metabolik dengan karakteristik hiperglikemik yang terjadi karena kelainan sekresi insulin, kerja insulin, atau kedua-duanya. Pengobatan Diabetes Mellitus dapat juga dilakukan dengan mengonsumsi obat-obatan herbal, salah satunya dengan menggunakan biji rambutan. Hal tersebut dikarena biji rambutan mengandung Polifenol, Tanin, Flavonoid, Saponin, Alkaloid, dan Steroid yang memiliki manfaat sebagai antidiabetes yang dapat menurunkan kadar gula darah di dalam tubuh dan juga sebagai antioksidan.

Cara pengolahan ramuannya juga tidak rumit, sehingga dapat diolah sendiri tanpa memerlukan peralatan khusus dan biaya besar. Adapun cara pengolahan yang dapat dilakukan adalah mengumpulkan biji rambutan terlebih dahulu, dicuci sampai bersih, kemudian dijemur. Setelah itu disangrai dan ditumbuk hingga halus. Hasil tersebut dijadikan sebagai kopi yang akan dikonsumsi untuk penderita Diabetes Mellitus. Ramuan tersebut tidak hanya untuk penderita Diabetes Mellitus, melainkan dapat menjadi ramuan pencegah penyakit bagi masyarakat yang belum menderita Diabetes Mellitus.

Pengobatan penyakit pada masyarakat pedesaan cenderung lebih menggunakan obat tradisional yang berasal dari tumbuh-tumbuhan atau biji-bijian. Hal ini disebabkan oleh beberapa faktor. Pertama, tumbuhan obat mudah didapat di sekitar lingkungan tempat tinggal mereka atau di hutan yang tidak jauh dari desa mereka. Kedua, letak daerah yang jauh dari kota dan sarana kesehatan masih kurang, sehingga dalam memperoleh obat-obatan tersebut membutuhkan waktu yang lama. Ketiga, ditinjau dari segi ekonomi, obat-obatan tradisional relatif lebih murah bahkan dapat diperoleh secara gratis tanpa harus mengeluarkan biaya, sedangkan obat-obatan modern harganya lebih mahal, sehingga tidak terjangkau oleh masyarakat yang tingkat pendapatannya rendah.

\section{B. Metode}

Kegiatan ini dilakukan pada hari Minggu, tanggal 8 November 2020 yang dilaksanakan di Desa Lamaran Tarung Kecamatan Cantigi-Kabupaten Indramayu, tepatnya berada di wilayah kerja UPTD Puskesmas Cantigi. Dalam pelaksanaan kegiatan, seluruh anggota tim akan melakukan penyuluhan permasalahan 
kesehatan, yaitu penyakit Diabetes Mellitus yang meliputi pengenalan penyakit diabetes mellitus, faktor pendukung penyakit diabetes mellitus, sasaran yang mengkin menderita penyakit diabetes mellitus, cara mencegah yang mencakup pola hidup masyarakat, sekaligus mengatasi masyarakat yang sudah menderita penyakit diabetes mellitus. Penyuluhan berupa pemberian materi kepada masyarakat di desa tersebut. Metode dalam Pengabdian ini menggunakan Mix Methood dengan pendekatan deskritif yang digunakan dalam pelaksanaan program sebagai berikut :

\section{a) Penyuluhan}

Metode pendekatan pengabdian masyarakat ini dilakukan dalam bentuk penyuluhan berupa penyampaian materi kepada masyarakat di desa lamaran tarung. Penyuluhan menyampaikan materi berupa konsep A Bilgates dan Si Dia (Awali Biasakan Cegah Diabetes dan Atasi Diabetes) yang diharapkan agar meningkatkan pemahaman serta pengetahuan masyarakat tentang Diabetes Mellitus.

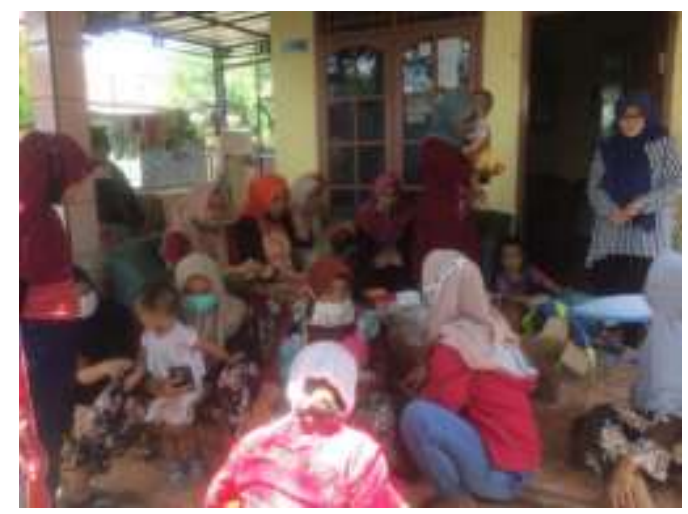

\section{Gambar 2. Dokumentasi Proses Penyuluhan}

Berdasarkan gambar di atas, dapat diketahui bahwa penyuluhan berlangsung dengan cukup lancar dan dilakukan menggunakan metode ceramah dan diskusi atau sesi tanya jawab.

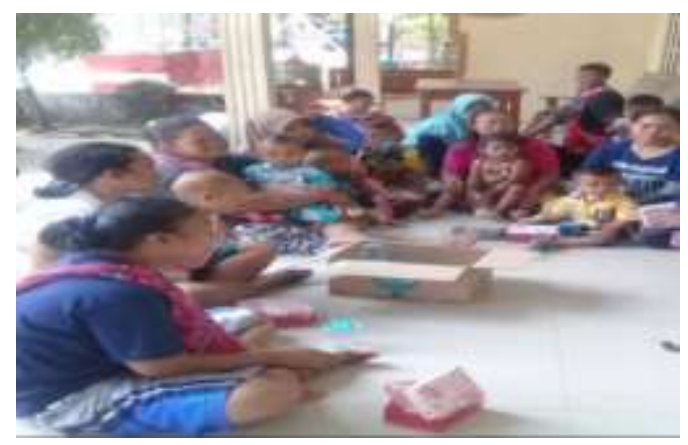

Gambar 3. Dokumentasi Partisipan Pengabdian Kepada Masyarakat 


$\begin{array}{ll}\text { ABDI WIRALODRA } & \text { ISSN 2656-5501 (Print) } \\ \text { JURNAL PENGABDIAN KEPADA MASYARAKAT } & \text { ISSN 2714-8041 (Online) }\end{array}$

Berdasarkan gambar di atas dapat dilihat bahwa partisipan yang ikut terlibat dalam kegiatan penyuluhan ini cukup banyak, yaitu sekitar 28 orang yang mana mereka merupakan warga di Desa Lamaran tarung. Partisipan yang terlibat mayoritas merupakan perempuan yang berprofesi sebagai ibu rumah tangga.

\section{b) Demonstrasi}

Metode pendekatan juga dilakukan dengan menggunakan demonstrasi, yaitu pendemonstrasian tata cara pembuatan ramuan kopi biji rambutan sebagai obat herbal dari penyakit Diabetes Melitus. Adapun cara pengoohan kopi biji rambutan adalah sebagai berikut:

1) Pisahkan biji rambutan dengan buahnya

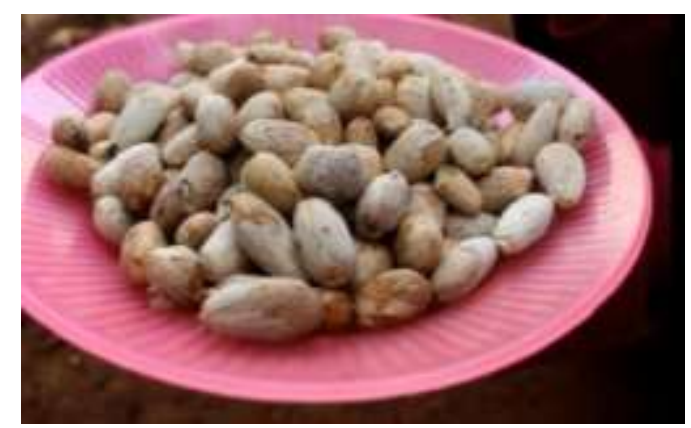

Gambar 4. Biji Rambutan

Tahap pertama yang perlu dilakukan dalam pembuatan kopi biji rambutan adalah memisahkan biji rambutan dengan buahnya, seperti gambar di atas.

2) Jemur biji rambutan hingga kering

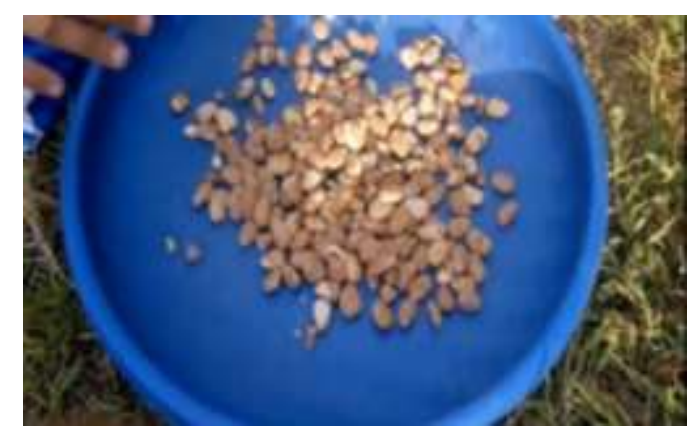

\section{Gambar 5. Dokumentasi Proses Penjemuran Biji Rambutan}

Tahap selanjutnya adalah proses penjemuran biji rambutan di bawah sinar matahari seperti gambar di atas guna mengurangi kadar air yang terkandung di dalam biji rambutan tersebut. 
3) Sangrai biji rambutan hingga kehitaman

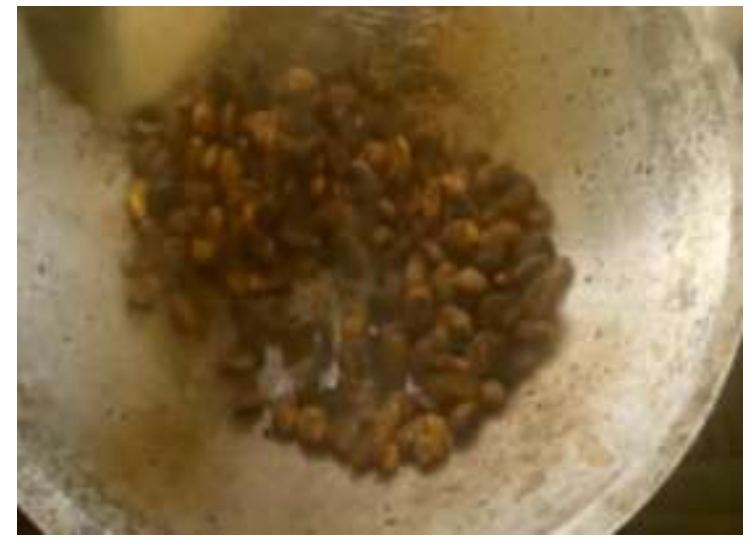

\section{Gambar 6. Dokumentasi Proses Penyangraian Biji Rambutan}

Setelah biji rambutan mengering, kemudian biji rambutan akan digoreng tanpa minyak atau disangrai sampai biji rambutan tersebut berubah warnanya menjadi kehitaman seperti gambar di atas.

4) Haluskan biji rambutan yang telah disangrai

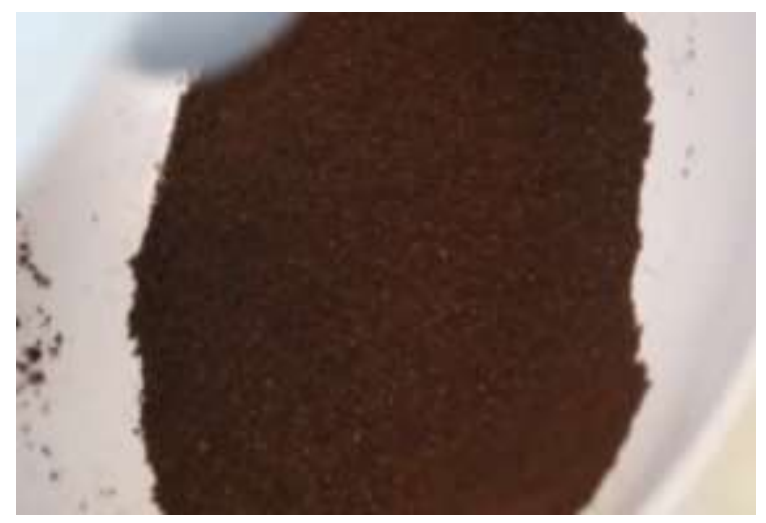

Gambar 7. Kopi Biji Rambutan

Langkah terakhir dalam proses pembuatan kopi biji rambutan adalah menumbuk atau menghaluskan biji rambutan yang sudah disangrai tersebut hingga bentuknya menyerupai kopi seperti gambar di atas. Jika sudah berbentuk menyerupai kopi, ramuan kopi biji rambutan sudah selesai dan siap untuk dikonsumsi dengan cara diseduh dengan segelas air.

c) Observasi

Metode pendekatan dilakukan dalam bentuk observasi dengan mengamati permasalahan dan mengidentifikasi permasalahan yang dibutuhkan pada tahap awal/persiapan. Dengan observasi pula dibutuhkan dalam menganalisis (membandingkan) pada tahap pelaporan. 


\section{ABDI WIRALODRA \\ ISSN 2656-5501 (Print) \\ JURNAL PENGABDIAN KEPADA MASYARAKAT \\ ISSN 2714-8041 (Online)}

\section{Hasil dan Pembahasan}

Kegiatan pengabdian kepada masyarakat yang dilakukan dalam bentuk penyuluhan dan pemerikasaan gula darah, serta pendemontrasian cara pembuatan kopi biji rambutan ini berjalan dengan lancar. Pengabdian kepada masyarakat tersebut dilaksanakan pada tanggal 8 November 2020 di Desa Lamaran Tarung Kecamatan Cantigi Kabupaten Indramayu.

Pelaksanan kegiatan pengabdian kepada masyarakat ini dilakukan oleh 5 (orang) orang tim pengabdi dengan jobdesk sebagai berikut: (a) Menyampaikan materi atau melakukan penyuluhan mengenai Diabetes Mellitus [1 orang]. (b) Memeriksa gula darah para partisipan/responden yang datang [3 orang]. (c) Mendemonstrasikan pembuatan kopi biji rambutan sebagai obat herbal Diabetes Mellitus [1 orang].

Pengabdian masyarakat diawali dengan melakukan penyuluhan mengenai Diabetes Mellitus baik dari tanda gejala, penyebab, cara pencegahan, sampai dengan cara mengatasinya. Penyuluhan yang dilakukan ini menambah pengetahuan masyarakat mengenai Diabetes Mellitus serta memberi wawasan mengenai penggunaan obat herbal untuk mengatasi penyakit Diabetes Mellitus berupa biji kopi rambutan.

Berdasarkan penyuluhan yang dilakukan, masih banyak masyarakat yang kurang paham menganai Diabetes Mellitus baik itu penyebabnya maupun cara menanganinya. Masyarakat juga belum mengetahui manfaat dari biji rambutan yang selama ini dianggap sebagai limbah yang sebenarnya bisa dikembangkan sebagai obat herbal yang memiliki khasiat untuk menurunkan kadar gula. Dengan adanya pengabdian ini, masyarakat mampu memanfaatkan biji rambutan sebagai ramuan pencegah sekaligus mengatasi penyakit Diabetes Mellitus.

Setelah dilakukan penyuluhan dengan metode ceramah dan tanya jawab, kemudian para partisipan/responden yang datang pun diperiksa kadar gula darahnya oleh tim pengabdi. Setelah dilakukan pemeriksaan gula darah pada 28 responden yang datang didapatlah presentase perbadingan antara responden yang memiliki gula darah normal dan tinggi sebagai berikut: 


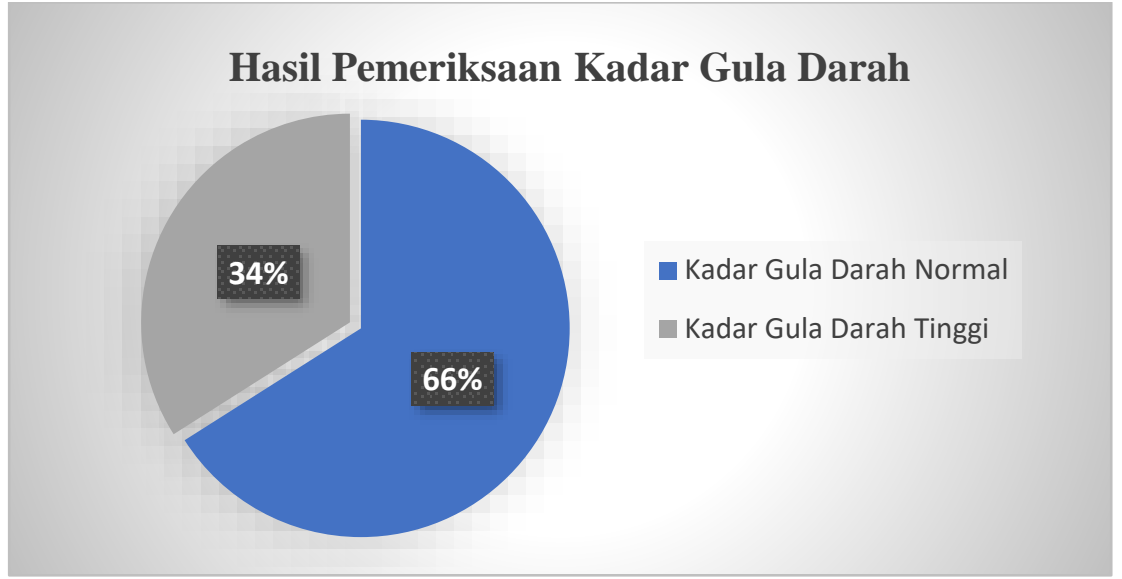

Gambar 8. Perbandingan Hasil Pemeriksaan Kadar Gula Darah

Berdasarkan diagram lingkaran di atas, dapat dilihat bahwa dari 28 responden yang datang terdapat setidaknya $34 \%$ diantaranya memiliki kadar gula darah yang tinggi. Hal tersebut menandakan masih minimnya pengetahuan masyarakat mengenai Diabetes Mellitus khususnya cara pencegahan dan cara mengatasinya.

Oleh karena itu, pengabdian ini diharapkan dapat meningkatkan pemahaman masyarakat mengenai Diabetes Mellitus terutama hal yang perlu dilakukan guna mengatasi Diabetes mellitus tersebut. Selanjutnya pengabian masyarakat ini dilanjut dengan pendemonstrasian pembuatan kopi biji rambutan sebagai salah satu upaya untuk mengatasi Diabetes Mellitus.

Proses pembuatan kopi biji rambutan ini tidaklah sulit, pertama-tama kita hanya perlu mengumpulkan biji rambutan terlebih dahulu, lalu dicuci sampai bersih dan dijemur agar kadar air didalam biji rambutan tersebut berkurang. Setelah biji rambutan mengering, kemudian sangrai biji rambutan tersebut hingga menjadi kehitaman lalu tumbuk hingga halus dan berbentuk menyerupai kopi.

Kopi biji rambutan pun dibagikan kepada para responden khususnya pada responden yang memiliki kadar gula darah yang tinggi. Kemudian beberapa diantara responden yang memiliki kadar gula darah yang tinggi tersebut pun dilakukan pemantauan atau monitoring selama 3 minggu guna mengetahui atau membuktikan bahwa terdapat perubahan kadar gula darah seseorang setelah mengonsumsi kopi biji rambutan ini. Adapun hasil pemantauan atau monitoring yang dilakukan selama 3 minggu tersebut, adalah sebagai berikut: 


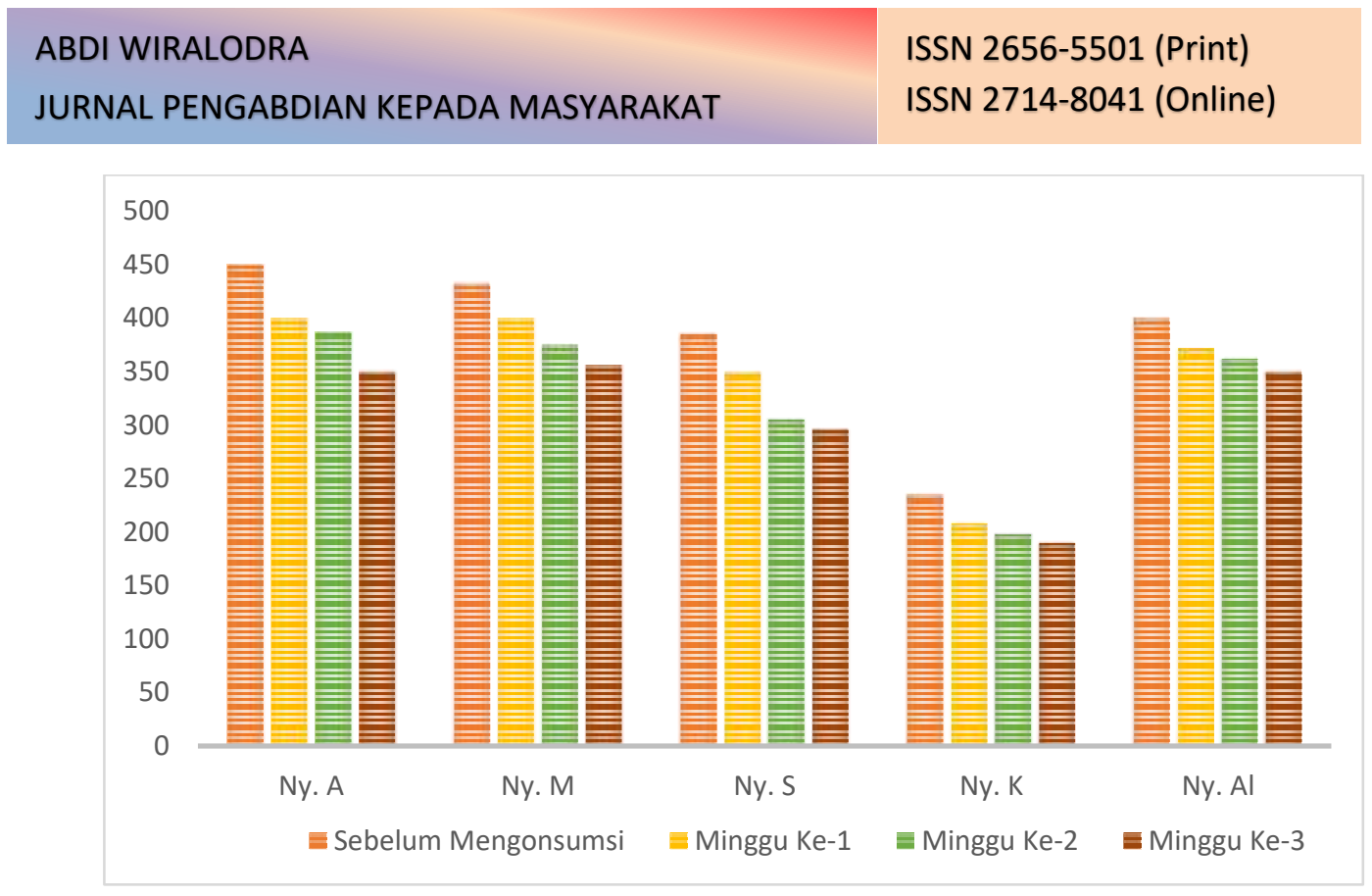

\section{Gambar 9. Hasil Pemantauan atau Monitoring Beberapa Responden}

Berdasarkan diagram di atas dapat disimpulkan bahwa terdapat penurunan kadar gula darah yang cukup signifikan setelah mengonsumsi kopi biji rambutan secara rutin selama 3 (tiga) minggu dengan dosis 2 sendok makan dan diseduh dengan air panas $150 \mathrm{ml}, 1 \mathrm{x}$ sehari sebelum makan. Hal tersebut menandakan bahwa penggunaan kopi biji rambutan sebagai upaya untuk mengatasi penyakit Diabetes Mellitus cukup efektif karena kopi biji rambutan ini dapat menrunkan kadar gua darah di dalam tubuh.

Hal tersebut sesuai dengan penelitian yang dilakukan oleh Ibrizah, Malinda Farikatul (2017) dalam Central Library of Maulana Malik Ibrahim State Islamic University of Malang menyatakan bahwa terdapat pengaruh pemberian biji kopi rambutan terhadap penurunan kadar gula darah karena pada kopi biji rambutan tersebut mengandung Polifenol, Tanin, Flavonoid, Saponin, Alkaloid, dan Steroid yang memiliki manfaat sebagai antidiabetes.

Hasil kegiatan pengabdian kepada masyarakat ini secara garis besar mencakup beberapa komponen sebagai berikut. (1) Keberhasilan target jumlah peserta pelatihan. (2) Ketercapaian tujuan pengabdian. (3) Ketercapaian target konsep pengabdian yang telah direncanakan. (4) Ketercapaian materi yang telah direncanakan. (5) Efektivitas pengonsumsian kopi biji rambutan sebagai upaya untyuk mengatasi Diabestes Mellitus.

Jumlah peserta yang hadir dalam kegiatan pengabdian masyarakat ini adalah sebanyak 28 orang. Hal tersebut menandakan bahwa peserta yang hadir telah 
mencapai $80 \%$ dari 35 orang yang ditargetkan oleh tim pengabdi. Angka tersebut menunjukkan bahwa kegiatan pengabdian kepada masyarakat jika dilihat dari jumlah peserta yang mengikuti dapat dikatakan berhasil.

Ketercapaian tujuan pengabdian kepada masyarakat ini secara umum sudah baik, karena pengabdian ini dapat menambahkan wawasan masyarakat mengenai Diabetes Mellitus dan membuat masyarakat menjadi mampu membuat kopi biji rambutan sendiri sebagai salah satu upaya untuk menanganoi Diabetes Melitus. Selain itu, pengabdian ini pun diharapkan dapat menurunkan angka penderita Diabetes Mellitus di daerah tersebut sesuai dengan tujuan diadakannya pengabdian ini.

Ketercapaian target konsep pengabdian pun sudah baik, karena secara keseluruhan dimulai dari proses penyuluhan, pemeriksaan gula darah, sampai dengan pendemonstrasian pembuatan kopi biji rambutan semuanya dapat terlakana dengan cukup baik.

Ketercapaian target materi pada kegiatan pengabdian kepada masyarakat ini cukup baik, karena materi penyuluhan telah dapat disampaikan secara keseluruhan. Materi pengabdian kepada masyarakat yang telah disampaikan adalah mengenai Diabetes Mellitus baik dari tanda gejala, penyebab, cara pencegahan, sampai dengan cara mengatasinya.

Pengonsumsian kopi biji rambutan sebagai upaya untuk mengatasi Diabestes Mellitus pun terbukti efektif. Hal tersebut didapat dari hasil pemantauan kepada beberapa orang yang memiliki gula darah tinggi yang dilakukan selama tiga minggu yang menunjukan hasil bahwasanya terdapat perubahan atau penurunan kadar gula darah secara signifikan setelah orang tersebut mengonsumsi kopi biji rambutan.

Secara keseluruhan kegiatan pengabdian kepada masyarakat melalui kegiatan penyuluhan dengan konsep A Bilgates dan Si Dia (Awali Biasakan Cegah Diabetes dan Atasi Diabetes) ini dapat dikatakan berhasil.

Keberhasilan ini selain diukur dari kelima komponen di atas, juga dapat dilihat dari kepuasan peserta setelah mengikuti kegiatan. Manfaat yang diperoleh para responden yang mengikuti pengabdian ini adalah responden menjadi lebih memahami mengenai penyakit Diabetes Mellitus dan juga memiliki keterampilan 
ABDI WIRALODRA

JURNAL PENGABDIAN KEPADA MASYARAKAT
ISSN 2656-5501 (Print)

ISSN 2714-8041 (Online)

untuk membuat ramuan kopi biji rambutan yang dapat menurunkan kadar gula darah.

\section{Kesimpulan dan Saran}

Setelah diadakannya pengabdian kepada masyarakat ini, pengetahuan masyarakat mengenai Diabetes Mellitus mengalami peningkatan, baik mengenai pencegahan maupun pengobatan Diabetes Mellitus. Berdasarkan hasil dan pembahasan, dapat disimpulkan bahwa seseorang yang mengonsumsi biji rambutan dapat mengalami penurunan kadar gula darah secara signifikan. Akan tetapi, pola makannya perlu memperhatikan kadar gula yang dikonsumsi.

Untuk pengabdian kepada masyarakat selanjutnya diharapkan dapat mengkaji mengenai efektivitas buah mengkudu dalam menurunkan kadar gula dalam darah.

\section{DAFTAR PUSTAKA}

Ibrizah, Malinda Farikatul. 2017. Pengaruh Pemberian Ekstrak Etanol 70\% Biji Rambutan (Niphelium Lappaceum L.) Binjai Terhadap Kenaikan Kadar HDL dan Perununan kadar LDL pada Mencit (Mus Musculus) Jantan yang diinduksi Streptozotosin. Central Library of Maulana Malik Ibrahim State Islamic University of Malang.

Ramadha, A. N. dkk. 2018. Penerapan Konsumsi Biji Rambutan Terhadap Penurunan Kadar Gula Darah Pada Penderita Diabetes Melitus di Kampung Gendingan Jebres Surakarta. Working Paper. Stikes 'Aisyiyah Surakarta.

Afika, M. dkk. 2019. Efek Ekstrak Etanol Biji Rambutan (Nephelium Lappaceum L.) Dalam Menurunkan Kadar Glukosa Darah Puasa Mencit Model Diabet. Universitas Islam Bandung Repository.

Yuda, A. 2015. Kandungan Metabolit Sekunder dan Efek Penurunan Glukosa Darah Ekstrak Biji Rambutan (Nephelium Lappaceum L) Pada Mencit (Mus Musculus). Jurnal Sains dan Kesehatan. 1 (3) : 120-125.

Damayanti, S. 2015. Diabetes Mellitus \& Penatalaksanaan Keperawatan. Yogyakarta: Nuha Medika.

Hasdianah. 2014. Mengenal Diabetes Mellitus pada Orang Dewasadan Anak-Anak Dengan Solusi Herbal. Yogyakarta: Nuha Medika.

Oetari. 2019. Khasiat Obat Tradisional Sebagai Antioksidan Diabetes. Jakarta: Andi Publisher.

Decroli, E. 2019. Diabetes Mellitus Tipe 2. Padang: Bagian Ilmu Penyakit Dalam Fakultas Kedokteran Universitas Andalas.

Dalimartha, S. dan Felix Adrian. 2017. Buah, Sayur, \& Herbal Untuk Penderita Diabetes Mellitus. Jakarta: Penebar Swadaya.

Ermawati, dan A. h. Sulaiha. 2019. Efek Pemberian Seduhan Serbuk Biji Rambutan (Nephelium Lappaceum L) Terhadap Penurunan Gula Darah Mencit (Mus Musculus). Jurnal Kesehatan Yamasi Makassar. 3 (2). 